\title{
Primary Elections and the Collective Right of Freedom of Association
}

The federal courts have yet to articulate a unified doctrine covering state regulation of participation in primary elections. ${ }^{1}$ Such a doctrine must be able to resolve three types of challenges. First, independent voters may challenge a state-mandated closed primary, ${ }^{2}$ claiming that they have a right to vote in that primary election. Second, a political party ${ }^{3}$ may challenge a state-mandated open primary on the grounds that it includes voters lacking a right to participate in that primary election. Finally, a political party may challenge a state-mandated closed primary claiming the state regulations exclude voters who have a right to participate in the primary. The Supreme Court has to date addressed only the first two of these challenges: an independent voter's challenge to a closed primary and a political party's challenge to an open primary. The independent voter's claim of right to be included and the political party's claim of right to exclude cannot be reconciled. The Supreme Court, however, has analyzed

1. The United States Constitution leaves voting qualifications and the manner of conducting presidential, congressional, and state elections to state law. U.S. ConST. art. I, $\S 2, \mathrm{cl}$. 1; art. I, $\S 4, \mathrm{cl}$. 1; amend. X; amend. XVII. The Constitution does impose certain restrictions on states' ability to set voting qualifications. U.S. CoNST. amend. XV (prohibits abridgement of right to vote on account of race); amend. XIX (prohibits abridgement of right to vote on account of sex); amend. XXVI (prohibits abridgement of right to vote of those eighteen years of age or older on account of age).

The Constitution makes no explicit provision for state regulation of primaries. Direct applicability of the Constitution to primary elections remained uncertain until Nixon v. Herndon, 273 U.S. 536 (1927) (declaring state law prohibiting black voters from participation in primary elections contrary to Fourteenth Amendment). The courts have yet to hammer out all the contours of the Constitution's application to primaries.

2. Three types of primary elections currently exist: the closed primary, the open primary, and the blanket primary. Only members of a particular political party may participate in that party's closed primary. Any registered voter may participate in an open primary without affiliating himself with any particular party, but each voter may vote for the candidates of only one party. Any registered voter may also participate in a blanket primary, but the voter may distribute his votes among the various parties just as he may in a general election. See Note, The Constitutionality of Non-Member Voting in Political Parly Primary Elections, 14 Willamette L.J. 259, 261 (1978).

3. In the past, when a political party has brought suit, it has alleged an infringement of the rights of its members. Thus, when a political party can sue, any party member could also sue. Cf. NAACP v. Alabama ex rel. Patterson, 357 U.S. 449, 458-59 (1958) (close relationship between association and its members enables association to assert rights of its members). 
each challenge in isolation, and has not explained why one claimed right to participate in a primary should take precedence over the other. As a result, the Court has provided no express guidance for resolution of the third type of challenge to state regulation of primary elections.

This Note proposes a new conceptual framework, based on a collective right of freedom of association, for analyzing challenges to state regulation of participation in primaries. After discussing how this doctrine harmonizes past case law, the Note elaborates on the associational right of a political party to establish its own boundaries, and analyzes the application of this doctrine to challenges courts have not yet addressed.

\section{Glarification of the Right at Issue}

The Supreme Court has employed only a minimal scrutiny test to uphold a state-mandated closed primary against an independent voter's challenge. ${ }^{4}$ This disposition indicates that independent voters have no protected right to vote in a primary. In sharp contrast, the Court has applied strict scrutiny to invalidate a state-mandated open primary challenged by a political party. ${ }^{6}$ In Democratic Party $v$. Wisconsin, ${ }^{6}$ the Court concluded that political party members do have a right to vote in a primary and that they may even assert that right to bar independent voters from the primary. ${ }^{\text {? }}$

These holdings appear inconsistent in the context of the major precedents in this field, which suggest that the right at issue in disputes over state regulation of primary elections is the right to vote. ${ }^{8}$ Such a reading of these precedents is overly broad, ${ }^{9}$ however, and confuses the constraints

4. See Rodriguez v. Popular Democratic Party, 457 U.S. 1, 14 (1982) (political party not required to include nonmembers in procedure to select replacement for deceased commonwealth legislator; Court reasoned that procedure was analogous to party primary election); Nader v. Schaffer, 429 U.S. 989 (1976), affg without opinion 417 F. Supp. 837 (D. Conn.) (using minimal scrutiny to uphold state-mandated closed primary challenged by independent voter).

5. Democratic Party of the United States v. Wisconsin ex rel. La Follette, 450 U.S. 107 (1981) (invalidating Wisconsin law requiring delegates to party's national presidential convention to vote in accord with results of state's open primary); see also Cousins v. Wigoda, 419 U.S. 477 (1975) (state law contrary to national party's rules on selection of delegates to national convention violated party's freedom of association); O'Brien v. Brown, 409 U.S. 1, 5 (1972) (issuing stay to permit convention its traditional power to pass on credentials of delegates chosen in accordance with state law but in violation of party rules). Contra Heavey v. Chapman, 93 Wash. 2d 700, 611 P.2d 1256 (1980) (en banc) (decision prior to Democratic Party upholding blanket primary challenged by political party).

6. Democratic Party of the United States v. Wisconsin ex rel. La Follette, 450 U.S. 107 (1981).

7. Id. at 121-22 (party members have right to hold primary free from influence of nonmembers).

8. See, e.g., Smith v. Allwright, 321 U.S. 649 (1944) (party's exclusion of black voters from primary violates Fifteenth Amendment); United States v. Classic, 313 U.S. 299, 321-26 (1941) (willful altering and false counting and certification of primary ballots infringes constitutionally protected right to choose Congressional representative); see also Comment, Freedom of Association or Forced Association: Democratic Party of the United States v. Wisconsin ex rel. La Follette, 1982 DEr. C.L. REv. 173, 184 (decision in Democratic Party infringes right to vote).

9. Two factors, for example, significantly narrow the holding of Classic. First, in the congres- 


\section{Primary Elections}

imposed by state action with the protection accorded to the right to vote. ${ }^{10}$

sional district at issue, victory in the Democratic primary had always been equivalent to victory in the general election. 313 U.S. at 308. The primary was, in effect, the only election. Id. at 314 . Second, Classic repeatedly emphasizes that it concerns the right of "qualified" voters to have their ballots counted. Id. at $307,314,315$. The opinion never suggests that Republicans have a right to vote in the Democratic primary; the right to have one's primary ballot counted in the Democratic primary apparently extends only to Democrats. Classic, therefore, cannot be reduced to a holding that there is a "right to vote" in a primary election. Cf. Nader v. Schaffer, 417 F. Supp. 837, 843 (D. Conn.), aff d mem., 429 U.S. 989 (1976) (distinguishing Classic because Connecticut not a one-party state). Smith v. Alluright, like Classic, is factually limited to virtually one-party states. 321 U.S. at 659-60. Likewise, Terry v. Adams, 345 U.S. 461 (1953), is limited to cases in which victory in a private primary is equivalent to victory in the general election. Id. at 469 (plurality opinion) (Fifteenth Amendment applied if Jaybirds held private equivalent of prohibited election); id. at 483-84 (Clark, J., concurring) (since winners of Jaybird primary were always elected, Jaybird primary was the real election).

This narrower reading of these primary cases does not eliminate all regulation of primaries. It does not, for example, dissolve the constitutional ban on "white primaries." Smilh v. Allwright does establish more generally that where a state utilizes a primary election to select candidates for the general election ballot, the party's action is state action. 321 U.S. at 663 . Thus the suspect classification branch of the equal protection clause would prohibit classifications based on race in the context of a primary election even if victory in a primary election were not always equivalent to a general election victory. See Nixon v. Condon, 286 U.S. 73, 89 (1932) (where political party's action is state action, party's exclusion of black voters from primary violates equal protection clause); Nixon v. Herndon, 273 U.S. 536, 541 (1927) (state's exclusion of black voters from primary violates equal protection clause).

10. The Court's invocation of the Fifteenth Amendment and the one person, one vote standard in its cases involving primary elections does suggest that participation in a primary is part of the right to vote in a general election. E.g., Gray v. Sanders, 372 U.S. 368 (1963); Smith v. Allwright, 321 U.S. 649 (1944). Though Sinith v. Allwright appears to connect the right to vote in a primary to the right to vote in a general election, 321 U.S. 649, 661-62 (1944), Smith really establishes only that a party's action is state action when the state incorporates the party's behavior by automatically placing primary winners on the general election ballot. Id. at 663. See also supra note 9 .

In Gray v. Sanders, 372 U.S. 368, 378-80 (1963), the Court utilized the one person, one vote standard to invalidate a state law requiring the use of a county-unit system as the basis for counting primary election votes. While the Court's invocation of Baker v. Carr might suggest that the right to vote in a general election was involved, the Court did not rely on that fundamental interest, but rather reasoned that the county-unit system, which distinguished among voters on the basis of geographic location, constituted an impermissible basis of distinction under the equal protection clause. 377 U.S. at $378-80$. The holding thus reflects the fact that the conduct of a party primary is state action and that the equal protection clause therefore applies. The Court never suggested, however, that a distinction between party members and nonmembers was similarly impermissible for purposes of the equal protection clause.

The conflict among the lower federal courts over whether the one person, one vote standard applies to party activity other than primary elections also reflects a debate over state action rather than over the right to vote. State action exists where the state has made the party's action integral to its electoral system. See Moore v. Ogilvie, 394 U.S. 814 (1969) (state's use of nominating petitions to obtain place on ballot is integral part of elective system). Compare Maxey v. Washington State Democratic Comm., 319 F. Supp. 673, 678 (W.D. Wash. 1970) (convention to nominate candidates is anaiogous to primary election and therefore state action) with Lynch v. Torquato, 343 F.2d 370, 372 (3d Cir. 1965) (no state action in election of county committee which conducted internal party affairs) and Dahl v. Republican State Comm., 319 F. Supp. 682, 684-85 (W.D. Wash. 1970) (no state action in election of state committee performing ministerial functions for party). See also Seergy v. Kings County Republican County Comm., 459 F.2d 308, 313-14 (2d Cir. 1972) (not discussing state action, but holding that one person, one vote did not apply to voting by party committee members who performed solely ministerial functions, but did apply if committee members performed "public electoral functions").

The "white primary" and one person, one vote cases should therefore not be read as establishing a right to vote in a primary; they establish only that a political party's action with regard to a primary election is state action because the state grants "preferential ballot access" to nominees of political parties in determining who is placed on the general election ballot. Cf. L. Tribe, AMERICAN Constr- 
Moreover, the right to vote cannot logically explain the disparate legal standards applied, and results reached, in Democratic Party $v$. Wisconsin and Nader v. Schaffer. ${ }^{11}$ These cases can, however, be reconciled on the theory that the real rights at issue in both cases are the collective associational rights of the political party and its members. Democratic Party, in conjunction with $\mathrm{Nader}$, demonstrates that members of a political party have rights based in freedom of association which independent voters lack. ${ }^{12}$ This theory of associational rights explains why only political party members, not independent voters, have a right to vote in a primary election. ${ }^{13}$

TUtional. LAW 790 (1978) (noting, however, that Supreme Court has yet to recognize explicitly this state action principle). While sufficient to create state action, this connection between the state and the political party's primary election does not implicate the right to vote in a general election. As long as the state provides for alternative avenues for nominating a candidate for a general election, denying the right to participate in a party's primary election is not the same as denying the right to vote in that general election. E.g., American Party v. White, 415 U.S. 767, 782-83 (1974) (state cannot require so large a measure of community support that minority parties and independent candidates have no real chance to obtain ballot position); Bullock v. Carter, 405 U.S. 134, 143-44 (1972) (exclusionary filing fees infringe on franchise where system lacks alternative nominating procedure); Williams v. Rhodes, 393 U.S. 23, 31 (1968) (right to vote burdened if state bars minority parties from ballot).

11. 417 F. Supp. 837 (D. Conn.) (using minimal scrutiny to uphold state-mandated closed primary challenged by independent voter), affd mem., 429 U.S. 989 (1976).

To interpret the Fifteenth Amendment and one person, one vote cases, see supra note 10, to mean that voting in a primary is part of the right to vote in a general election would clash with the Court's use of rational-relation review to dismiss independent voters' challenges to closed primaries. Rodriguez v. Popular Democratic Party, 457 U.S. 1, 8, 13-14 (1982); Nader v. Schaffer, 417 F. Supp. 837 (D. Conn.), affd mem., 429 U.S. 989 (1976). Had these cases involved the right to vote in a general election, the Court would have applied strict scrutiny. Kramer v. Union Free School Dist. No. 15, 395 U.S. 621, 626 (1969) (right to vote in general election is fundamental interest protected by Fourteenth Amendment); Harper v. Virginia Bd. of Elections, 383 U.S. 663 (1966) (poll tax contravenes equal protection clause). The Court would also have applied strict scrutiny had these cases involved a distinction between political party members and nonmembers based on an invidious classification such as race. See Loving v. Virginia, 388 U.S. 1 (1967) (racial classification bears heavy burden of justification); Korematsu v. United States, 323 U.S. 214, 216 (1944) (racial classification subject to "rigid scrutiny"); Yick Wo v. Hopkins, 118 U.S. 356 (1886) (invalidating legislation particularly disadvantaging ethnic minority).

12. "Association" has been used by the courts in two senses, one personal and one political:

In one line of decisions, the Court has concluded that choices to enter . . . certain intimate

human relationships must be secured against undue intrusion by the State. . . . In this respect,

freedom of association receives protection as a fundamental element of personal liberty. In

another set of decisions, the Court has recognized a right to associate for the purpose of engag-

ing in those activities protected by the First Amendment . . . .

Roberts v. United States Jaycees, 104 S. Ct. 3244, 3249 (1984).

An individual has a right to associate with-meaning to support-the candidate of his choice. This individual "association" should not be confused with the political party's associational right to conduct its primary election, however. This individual association does not require that an individual be allowed to vote in a party primary. The individual associates with the candidate by giving money, by working in the candidate's campaign, or by supporting the candidate in the general election. Denying an individual the opportunity to vote for a candidate in a primary does not infringe this individual right of "freedom of association." Nader v. Schaffer, 417 F. Supp. 837, 840, 842 (D. Conn.) (independent voter excluded from primary suffered no infringement of right of association), affd mem., 429 U.S. 989 (1976).

13. This view does not conflict with the constitutional ban on "white primaries." See supra note 9. Where the party primary election is state action, the suspect classification branch of the Fourteenth 
Indeed, both Nader and Democratic Party specifically discuss some notion of freedom of association. Nader justified a state law excluding independent voters from a party's primary by pointing to the state's legitimate interest in protecting party members from any intrusion into their associational rights, including the right of candidate selection, by those with adverse political principles. ${ }^{14}$ In Democratic Party, the Gourt also relied on the right of political association of a party and its adherents, ${ }^{15}$ declaring that freedom of association confers on individuals associated together the right to determine their internal affairs free from the harmful influence of those unaffiliated with the party. ${ }^{16}$ Though a primary has external effects, the Court viewed it solely as an internal mechanism for party decisionmaking ${ }^{17}$ and unquestioningly accepted the political party's claim that inclusion of independent voters had harmed that mechanism. ${ }^{18}$

Although Democratic Party, like the cases preceding it, ${ }^{19}$ assumes a collective right ${ }^{20}$ of freedom of association possessed only by political party associates and not by independent voters, the Supreme Court has yet to articulate the nature or the contours of that right. Because past cases have focused on party autonomy in internal affairs, ${ }^{21}$ the cases can be read as

Amendment protects black voters. A major distinction between a rule barring blacks and a rule barring independent voters from participation in a primary lies in the fact that race is an unalterable characteristic, whereas party affiliation is freely adopted and easily altered. As Nader indicates, a party affiliation requirement imposes almost no burden on an individual's right to affiliate himself with the candidate of his choice. 417 F. Supp. at 842.

14. Nader v. Schaffer, 417 F. Supp. at $844-45$ (citing Ray v. Blair, 343 U.S. 214, 221-22 (1952)).

15. 450 U.S. at 121.

16. Id. at 122 .

17. Id. at 121-22. The Court made no mention of the fact that because the winner of the primary of one of the major parties is likely to win the general election, unaffiliated voters are interested in and affected by party primaries.

18. Id. at 123-24.

19. See Cousins v. Wigoda, 419 U.S. 477, 487 (1975) (party enjoys constitutional right of political association); Kusper v. Pontikes, 414 U.S. 51, 57 (1973) (state's supervision of primary elections infringed right of political association); Williams v. Rhodes, 393 U.S. 23, 31 (1968) (right to form political party means little if party can be kept off the ballot); NAACP v. Alabama ex rel. Patterson, 357 U.S. 449,460 (1958) (due process clause assures freedom to associate to advance shared beliefs).

20. The idea that certain constitutional guarantees run to groups rather than individuals has long been acknowledged. Some rights run to society as a whole. For example, New York Times Co. v. Sullivan, 376 U.S. 254, 268-72, 278-82 (1964), permits the press to print certain defamatory material to ensure that the public as a whole has access to an uninhibited marketplace of ideas. See also Curtis Publishing Co. v. Butts, 388 U.S. 130, 147-55 (1967) (plurality opinion) (discussing interest of the community in free circulation of information). This First Amendment collective right might well be labeled a "proxy right," as the entity becomes a holder of rights not solely for its own benefit but for that of the collectivity as well.

"Collective rights" also include rights which can be effectively exercised only by individuals acting in concert. The prohibition of intentional dilution of the voting strength of a particular group protects such a collective right. Rogers v. Lodge, 458 U.S. 613 (1982) (at-large voting system maintained for invidious purpose of diluting voting strength of black population is illegal); Gomillion v. Lightfoot, 364 U.S. 339 (1960) (Fifteenth Amendment violation to redefine city boundaries to disenfranchise black voters).

21. Democratic Party v. Wisconsin, 450 U.S. at 122 (party's ability to determine participation in 
suggesting that freedom of association involves a political party's right of privacy. A more exact determination of the nature of the right underlying these decisions will prove crucial, however, in resolving future challenges to state regulation of primary elections. This Note argues that freedom of association protects party primaries not merely because the primary process is "internal," but also because the state cannot stifle or inhibit robust political debate. Freedom of association is a right of speech, not a political party's right of privacy.

\section{Freedom of Association: The Nature of the Right}

The right of freedom of association derives from the First Amendment guarantees of free speech, the right to peaceably assemble, and the right to petition for redress of grievances. ${ }^{22}$ Freedom of association confers a right to join with others to pursue activities independently protected by the First Amendment. ${ }^{23}$

Opinions developing the right of freedom of association contain both an individualistic aspect and a collective aspect. ${ }^{24}$ In NAACP v. Alabama, for example, the Court "recognized the vital relationship between freedom to associate and privacy in one's associations" ${ }^{325}$ and noted that a membership disclosure requirement might subject individual members to reprisals. ${ }^{26}$ Yet in the same case, the Court also looked to effects on the association's ability to advocate the beliefs of its members. In protecting the ability of NAACP "members to pursue their collective effort to foster beliefs," the Court implicitly recognized that an association may be able to achieve objectives so far beyond individual capability as to be qualitatively differ$\mathrm{ent}^{\mathbf{2 8}}$ and ruled that the Constitution protects the ability of such an associ-

decisionmaking); Cousins v. Wigoda, 419 U.S. 477, 491 (1975) (convention itself was the proper forum for settling disputes as to which delegates should be seated); O'Brien v. Brown, 409 U.S. 1, 4-5 (1972) (per curiam) (protecting internal workings of political party convention).

22. Recognition of a separate right of freedom of association can be traced back to NAACP v. Alabama ex rel. Patterson, 357 U.S. 449, 460 (1958) (striking down membership disclosure requirement), and was developed in Bates v. City of Little Rock, 361 U.S. 516, 523 (1960) (striking down compulsory disclosure of membership lists), and NAACP v. Button, 371 U.S. 415, 430-31 (1963) (striking down law prohibiting organization from soliciting clients for attorney).

23. Roberts v. United States Jaycees, 104 S. Ct. 3244, 3249 (1984) (freedom of assaciation confers right to associate for purposes of engaging in those activities protected by the First Amendment); $L$. TRIBE, supra note 10 , at 701-02.

24. The individualistic aspect has received more attention than the collective aspect. For one example, see L. TRIBE, supra note 10 , at 700-01.

25. NAACP v. Alabama ex rel. Patterson, 357 U.S. 449, 462 (1958) (membership disclosure violates freedom of association).

26. Id. at 463 .

27. Id. (emphasis added).

28. Id. at 460 (effective advocacy of a point of view is "undeniably enhanced by group association") (emphasis added). See Buckley v. Valeo, 424 U.S. 1, 15 (1976) (per curiam) (NAACP recognized that association enhanced effective advocacy); Emerson, Freedom of Association and Freedom of Expression, 74 YALE L.J. 1, 4 (1964) (accumulation of resources and focus of effort enable association 


\section{Primary Elections}

ation to carry out the First Amendment activities of its members. ${ }^{29}$ Freedom of association confers on each member the right to combine and take advantage of an association whose whole may be greater than the sum of its parts. Any substantial state infringement of this right of freedom of association must be justified by a compelling state interest. ${ }^{30}$

\section{A. The Right of Political Association}

Because the First Amendment protects political advocacy and participation in partisan politics, freedom of association necessarily includes a right of political association which protects the right to form a political party for the advancement of partisan political beliefs. ${ }^{31}$ One way political parties advance shared beliefs is by selecting candidates representing those shared beliefs to run in a general election. ${ }^{32}$ If those candidates can attract sufficient popular support to be elected, the candidates can then effectuate the political party's programs.

A state infringes freedom of political association if it attempts to control

to achieve objectives beyond capacity of individual).

29. For additional support, see Buckley v. Valeo, 424 U.S. 1, 22 (1976) (per curiam) (because contribution enables like-minded persons to pool resources in furtherance of common political goals, limits on freedom to contribute implicate First Amendment interests); L. TRIBE, supra note 10, at 701-02 (current First Amendment doctrine protects only associations seeking independently protected constitutional goal).

30. E.g., Roberts v. United States Jaycees, 104 S. Ct. 3244, 3252 (1984) (requiring state to use least restrictive means to serve compelling state interest when right of freedom of association is at stake); Bates v. City of Little Rock, 361 U.S. 516, 524 (1960) (requiring compelling state interest to justify burden on freedom of association).

A state law violates freedom of association if it imposes a "substantial" burden on freedom of association. E.g., Bates v. City of Little Rock, 361 U.S. 516, 524 (1960); NAACP v. Alabama ex rel. Patterson, 357 U.S. 449, 462 (1958). The Court has not set forth standards for identifying a "substantial" interference. In Democratic Party, the Court uncritically accepted the party's assertion that the interference with its freedom of association was substantial. 450 U.S. at 123-24 (1981).

31. See Cousins v. Wigoda, 419 U.S. 477, 487 (1975) (party and its adherents enjoy a constitutional right of political association); id. at 491 (Rehnquist, J., concurring) (same); Kusper v. Pontikes, 414 U.S. 51, 56-57 (1973) (right to associate with others for common advancement of political beliefs and ideas); Williams v. Rhodes, 393 U.S. 23, 30-31 (1968) (right to form political party to advance political goals); $c f$. Roberts v. United States Jaycees, 104 S. Ct. 3244, 3252 (1984) (individual's right to petition government for redress requires correlative right to engage in group effort toward that end); Ripon Soc'y v. National Republican Party, 525 F.2d 567, 585 (D.C. Cir. 1975) (freedom of association protects political party's ability to effectuate change through the political process).

The right of political association developed out of NAACP v. Alabama, 357 U.S. 449, 462-63 (1958) (membership disclosure requirement unconstitutionally impairs associational freedoms). $N A A C P$ relied in part on the privacy interests stemming from the nature of the particular organization involved. $I d$. at 462 . The Court has subsequently found, however, that political parties have a right of freedom of association even though they, unlike the NAACP, are not organized around precisely defined ideological goals and even though their rules may permit virtually anyone to affiliate with them. See, e.g., Democratic Party v. Wisconsin, 450 U.S. at 121-22 (1981) (First Amendment protects right of political association); Cousins v. Wigoda, 419 U.S. 477, 487-91 (1975) (same); Kusper v. Pontikes, 414 U.S. 51, 56-57 (1973) (same); Williams v. Rhodes, 393 U.S. 23, 30-31 (1968) (First Amendment protection for right to form a political party).

32. See Kusper v. Pontikes, 414 U.S. 51, 58 (1973) (basic function of political parties is to select candidates to run in general election). 
the content of the beliefs advanced by a political party, ${ }^{33}$ if it interferes with a political party in such a way as to deny party members the advantages conferred by association, ${ }^{34}$ or if it inhibits the party's efforts to convince others to adopt the party members' shared beliefs. ${ }^{36}$ Such infringements on the freedom of political association can be upheld only if required by a compelling state interest. ${ }^{36}$

It may be argued that freedom of association confers lesser rights on political parties than on other groups because of the pervasive connections between states and political parties. According to this argument, because a state provides for primary elections at state expense and because the state strengthens political parties by conferring preferential general election ballot access upon candidates selected in party primaries, the state should be able to regulate political parties in ways that would infringe upon the freedom of association of other groups.

This argument mistakenly equates "state action" with the ability of the state to regulate a political party. The connections between state and party that make the party's action state action do give the state a greater interest in regulating political parties than in regulating other groups. But this does not mean that the state can avoid the required demonstration of a "substantial" state interest altogether; ${ }^{37}$ it merely makes the state's demonstration somewhat easier.

Furthermore, a state's leadership should not be able to immunize itself

33. Cf. Roberts v. United States Jaycees, 104 S. Ct. 3244, 3252 (1984) (state interest in regulating association must be unrelated to the suppression of ideas).

34. See, e.g., Buckley v. Valeo, 424 U.S. 1, 22 (1976) (per curiam) (government control of campaign financing infringed First Amendment interests); Cousins v. Wigoda, 419 U.S. 477 (1975) (state attempt to control delegate seating procedure for party national convention voided).

35. Cf. First Nat'l Bank v. Bellotti, 435 U.S. 765 (1978) (implying that an entity has First Amendment right to convince others to adopt its political position).

36. Williams v. Rhodes, 393 U.S. 23, 31 (1968) (requiring state to demonstrate compelling interest in its regulation of political parties).

37. The Court betrays some uncertainty in its standard of review of freedom of assaciation in election cases. The strict scrutiny it applies in such cases is not quite as "strict" as the " "strict" in theory and fatal in fact" standard described in Gunther, The Supreme Court, 1971 Term-Foruard: In Search of Evolving Doctrine on a Changing Court: A Model for a Neuer Equal Protection, 86 HaRv. L. Rev. 1, 8 (1972), applied in other areas.

The Court seems more willing to use a balancing test in election cases than it is in other cases. See Roberts v. United States Jaycees, 104 S. Ct. 3244, 3255 (1984) (permitting "incidental" abridgement of freedom of association); Anderson v. Celebrezze, 103 S. Ct. 1564, 1570 (1983) (identifying and weighing state's interests against First Amendment injuries); Williams v. Rhodes, 393 U.S. 23, 30 (1968) (same). Democratic Party's discussion of "substantial" state interests also suggests a balancing test. 450 U.S. at 126.

The Court's uncertainty about its standard of review is best reflected in its cases on ballot access requirements. Compare Williams v. Rhodes, 393 U.S. 23 (1968) (applying aggressive scrutiny to strike down ballot access requirement) with Jenness v. Fortson, 403 U.S. 431 (1971) (upholding ballot access requirements almost summarily while citing Williams $v$. Rhodes). Later cases continue to reflect this uncertainty. Compare American Party v. White, 415 U.S. 767 (1974) (upholding ballot access requirements because they served two compelling state interests) with Storer v. Brown, 415 U.S. 724 (1974) (remanding case to determine whether ballot access requirement too severe). 
from successful attack through the electoral process. Whether or not a state confers advantages on a political party, the state may not stifle or inhibit robust political debate ${ }^{38}$ or minimize the accountability of elected officials to their constituents. ${ }^{39}$ Any state regulation of political parties that substantially influences the content of beliefs or reduces the vigor of the party's pursuit of elected offices or new adherents will also inhibit debate and diminish accountability; such regulations should therefore be subject to strict scrutiny. ${ }^{40}$

\section{B. Participation in a Primary Election}

The right of political association must include the power of a political party to seek a compromise among the varied interests of its adherents ${ }^{41}$ without interference. ${ }^{42} \mathrm{~A}$ party's selection of its candidates plays a crucial role in striking such a balance among these interests: ${ }^{43}$ The primary election serves as a mechanism to determine the shared political ideals of

38. See New York Times Co. v. Sullivan, 376 U.S. 254, 270 (1964) ("profound national commitment to the principle that debate on public issues should be uninhibited, robust, and wide-open").

39. See L. TRIBE, supra note 10 , at 774 (courts should be wary of government's attempt to control the electoral system which is the fundamental check on its power); Mitau, Judicial Determination of Political Parly Organizational Autonomy: Some Recent Developments in the Law of Parties (1936-1957), 42 MiNN. L. REv. 245, 246 (1957) (one function of political parties is to hold government accountable to electorate). The goals of debate and accountability are interrelated. See De Jonge v. Oregon, 299 U.S. 353, 365 (1937) (must maintain opportunity for free political discussion so that government may be responsive to will of the people).

40. A state regulation might survive strict scrutiny if it could be argued that the state influenced the content of speech only in order to expand political debate. For example, in order to facilitate the formation of additional parties with alternative viewpoints, the state might constrain the oligopolistic powers conferred by the state on the two major parties. Cf. Red Lion Broadcasting Co. v. FCC, 395 U.S. 367, 390 (1969) (permitting government restraints on radio licensees in favor of others whose views should be expressed through this scarce medium: "It is the purpose of the First Amendment to preserve an uninhibited marketplace of ideas . . . rather than to countenance monopolization of that market, whether it be by the Government itself or a private licensee."). This possibility does not affect the parameters of the major parties' right to associate, however. If the state proves that its regulation intentionally and effectively enhances political debate, a court would have to weigh these First Amendment benefits against the First Amendment harms to the major parties. See supra note 37 (discussing balancing by courts in freedom of association cases).

41. Adherents' priorities can differ even though the individuals share a basic political outlook. A political party has positions on a broad range of issues, and adherents will have different priorities among those issues.

42. This consideration underlies the Court's use of freedom of association to protect political party conventions. See Cousins v. Wigoda, 419 U.S. 477, 490 (1975) (discussing party convention's need to form coalitions in process of candidate selection); O'Brien v. Brown, 409 U.S. 1 (1972) (per curiam) (protecting internal workings of party convention from state intrusion). Though the process of reaching a compromise is a process internal to the political party, that process is protected because its function is essential to the association, not merely because that process is "internal."

43. Note, Freedon of Association and Siate Regulation of Delegate Selection: Potential for Conflict at the 1984 Democratic National Convention, 36 VAND. L. REv. 105, 134 (1983) (in choosing candidates, party makes decisions reconciling varied interests of its adherents); cf. Opinion of the Justices to the Governor, 385 Mass. 1201, 434 N.E.2d 960, 963 (1982) (advisory opinion) (protecting party control over who party's candidate in general election will be), appeal dismissed, 460 U.S. 1057 (1983). 
party adherents by nominating those candidates that best express acceptable views on a wide range of issues. ${ }^{44}$ Any state interference with the party primary, including state-mandated inclusion of nonadherents, will distort the compromise struck between the varied interests of party adherents and therefore distort the party's determination of its shared political beliefs. ${ }^{45}$ Freedom of association bars such state control over a political party's determination of the content of its ideology.

Since control over participation in a primary can profoundly influence the content of the compromise emerging from the primary election, ${ }^{48}$ a political party's ability to define its boundaries cannot be separated from the party's ability to determine its political ideology. ${ }^{47}$ The right of political association, therefore, must protect the freedom of political party members to identify the people who constitute their association ${ }^{48}$ and to limit the association to those people. ${ }^{49}$ This includes the power to define membership or affiliation requirements in terms of commitment to shared party goals and the ability to determine whether would-be affiliates possess this commitment. ${ }^{\text {so }}$

44. Cf. Scott \& Carr, Political Parties Before the Bar: The Controversy Over Associational Rights, 5 U. Puget Sound L. REv. 267, 278 (1982) (primary election victors represent wishes of majority of party on wide range of political issues and thus represent the party position).

45. Note, supra note 43, at 134 (government intrusion easily disturbs political judgments and compromises made in selection of candidates).

46. Recognition of the possibility that the inclusion of nonadherents can distort the formulation of a political party's goals is amply demonstrated by state laws attempting to prevent "raiding." The state's interest in preventing raiding, see infra p. 131, reflects a concern that participation by nonmembers will influence the outcome of primary elections. Rosario v. Rockefeller, 410 U.S. 752,760 (1973) (upholding state's concern that voters in sympathy with one party will seek to influence or determine another party's primary).

47. See Roberts v. United States Jaycees, 104 S. Ct. 3244, 3258 (1984) (O’Connor, J., concurring in part and concurring in the judgment) ("Protection of the association's right to define its membership derives from the recognition that the formation of an expressive association is the creation of a voice, and the selection of members is the definition of that voice.").

48. See id. at 3252 (majority opinion) (state regulation which forces group to accept members it does not desire may impair original members' ability to express only those views that brought them together).

49. See id. (freedom of association presupposes a freedom not to associate); id. at 3254 (state regulation valid because it imposed no restriction on organization's ability to exclude individuals with ideologies or philosophies different from those of existing members); Democratic Party v. Wisconsin, 450 U.S. 107, 122 (1981) ("[T]his Court has recognized that the inclusion of persons unaffiliated with a political party may seriously distort its collective decisions-thus impairing the party's essential functions-and that political parties may accordingly protect themselves 'from intrusion by those with adverse political principles.' Ray v. Blair, 343 U.S. 214, 221-22."); Cousins v. Wigoda, 419 U.S. 477 , 487 (1975); Nader v. Schaffer, 417 F. Supp. 837, 845 (D. Conn.), affd mem. 429 U.S. 989 (1976).

50. Cf. Developments in the Law-Elections, 88 Harv. L. REv. 1111, 1169 n.88 (1975) [hereinafter cited as Developments (parties empowered to exclude persons unwilling to declare their affiliation). By implication, therefore, the party can determine how potential affiliates must demonstrate that they meet affiliation requirements. Such a determination could involve an examination of the beliefs of these potential affiliates. This ability to inquire into such beliefs or actions is necessary to implement the party's associational right to define its shared purposes and to set its own boundaries. See Democratic Party v. Wisconsin, 450 U.S. 107, 122 (1981). Because the party's action is state action in the context of primary elections, an individual may invoke some constitutional limits on the 
A political party's power to define its own boundaries is necessary to enable political party members to enjoy the advantages of association and to determine the content of their political speech. Together these powers create a constitutional right of political party adherents to conduct a primary free from the participation of nonadherents. The right to vote in a primary election thus vests only in individuals associated together in pursuit of shared political ideals. ${ }^{\text {si }}$

\section{Analytic Framework for Future Cases}

Because a political party has an associational right to exclude an independent voter from its primary, an independent voter's challenge to a closed primary must fail. For the same reason, a political party should succeed in its challenge to a state-mandated open primary. ${ }^{52}$ This associational doctrine can be extended to a political party's challenge of a statemandated closed primary. ${ }^{ }$In that challenge, as in previous challenges, a political party can argue that the state has violated the party's right of association by warping the determination of a party's shared beliefs.

\section{A. Definition of the Violation}

When a political party challenges a state-mandated open primary, it will argue that the open primary permits individuals with an insufficient degree of shared purpose to participate in a process essential to determining the shared ideals of party members. When a political party challenges a state-mandated closed primary, it can argue that the closed primary prohibits individuals with whom the party members wish to affiliate from

party's ability to inquire into individual beliefs and require that the party's inquiry be the least intrusive means capable of protecting its interests. Otherwise, the party's action might violate an individual right of privacy guaranteed by the Constitution.

51. For the right of association to exist, these individuals collectively must share some interest in order to constitute an association. See L. TRIBE, supra note 10, at 793 ("without a commonality of interest, there is little association to abridge"); Developments, supra note 50, at 1166 (exclusion cannot infringe associational interests unless some communality of interest exists between group and excluded individual); Note, Primary Elections: The Real Party in Interest, 27 RuTGers L. REv. 298, 306 (1974) (if group and individual aims are too divergent, no associational right arises).

52. A party raised this challenge in Democratic Party v. Wisconsin, 450 U.S. 107 (1981). The holding in Democratic Party is limited, however, because the Court framed the issue not as whether the state can hold an open primary but as whether the state can make the results of that primary binding on the party decisionmaking. Id. at 120. See also Anderson v. Growe, 546 F. Supp. 482, 486 (D. Minn. 1982) (refusing to enjoin Minnesota's open primary and limiting Democratic Parly to cases in which conflict exists between party rules and state law).

53. The only case presenting such a challenge to date is Republican Party of Conn. v. Tashjian, Civil No. H 54-548 (D. Conn. Dec. 5, 1984) (enjoining enforcement of state statute mandatory closed primary after state political party amended its rules to allow unaffiliated voters to vote in party primary for candidates for offices of United States Senator, United States Representative, and Governor). That decision rested on a political party's ability, guaranteed by freedom of association, to decide among alternative strategies for gaining electoral support. See slip op. at 5, 24-25, 27. 
participating in establishing those shared ideals. The two types of challenges by a political party thus raise the same issue: ${ }^{54}$ Does the right to define the group of party adherents who may participate in a primary belong to the party or the state?

Because the political party's designation of who may participate in a primary election is an essential element of its determination of its ideology, the right to determine participation in a primary should rest with the party in the first instance. A political party has the right to define its boundaries, unless the party's definition of who may participate in its primary election exceeds the commonality of purpose on which the right of association depends. Democratic Party expressly declares that it is for the political party-not the legislature or any court-"to determine the appropriate standards for participation in the Party's candidate selection process." ${ }^{\prime 3 s}$ A political party could thus determine that any voter who chooses to participate in its party primary has demonstrated sufficient interest to be considered a party affiliate even if that voter is not formally a party member.

Democratic Party places a burden on the state to show that its regulation of primary participation does not infringe the freedom of association of the political party and its associates. Democratic Party thus implicitly assumes that freedom of association creates a presumption that a party's designation of who may vote in its primary includes those-and only those-individuals who have associated together to advance some common goal protected by the First Amendment. ${ }^{.68}$ This is true whether the political party's definition of participation includes only individuals with an obviously shared purpose or includes individuals with diverse views whom

54. Both inclusion of voters with an insufficient degree of shared purpose and exclusion of voters with a sufficient degree of shared purpose to be party associates may cause the outcome of a primary to deviate from the actual shared goals of the party's adherents. Even if the outcome of the primary is unaffected, party leaders will be uncertain as to whether the outcome does represent the shared goals of the association. Cf. Scott \& Carr, supra note 44, at 280 (burden on associational rights due to political party's uncertainty as to whether it has chosen its own candidates in primary). Inclusion of individuals in a primary election raises issues identical to those raised by exclusion from a primary election. Each infringes upon the party's right to determine the consensus of its members. $C f$. Note, State Restrictions on Municipal Elections: An Equal Protection Analysis, 93 HARv. L. REv. 1491, 1491-92 (1980) (arguing for similar treatment of regulations including and excluding individuals from participation in a general election).

55. 450 U.S. at 124 n.27.

56. In Democratic Party, the Court declined to assess the party's determination of which individuals were associates of the political party:

It may be the case, of course, that the public avowal of party affiliation required by Rule $2 \mathrm{~A}$ provides no more assurance of party loyalty than does Wisconsin's requirement that a person vote in no more than one party's primary. But the stringency, and wisdom, of membership requirements is for the association and its members to decide-not the courts . . . .

450 U.S. at 123 n.25. Cf. Republican Party v. Tashjian, Civil No. H 54-548, slip op. at $20-22$ (D. Conn. Dec. 5, 1984) (if party opts to include "outsiders," state should not treat outsiders as intruders unable to share the interests underlying party's existence). 
the party wishes to recruit. Such a presumption is in accord with the principle that a political party may determine its ideological orientation by limiting the association to the individuals it chooses.

This presumption is also likely to accord with the truth: A political party will take care not to extend participation in its primary to those lacking a sufficient commonality of interest with party members. ${ }^{57}$ Moreover, this presumption minimizes the costs of error. A reverse presumption, favoring the state's determination of participation in a primary, would permit the state to immunize itself from attack by stifling political debate. $^{\text {s8 }}$

This interpretation of Democratic Party places the burden of persuasion on the state to show that its regulations do not exclude from a primary any individuals who have joined with party members in pursuit of common ends or include any individuals who have not so joined. To avoid a finding that a state regulation burdens associational rights, the state would have to prove that the party's determination of who may participate in its primary bears no relationship to the commonality of purpose that underlies the right of association, ${ }^{59}$ and thus that the state's regulations have not infringed the political party's right to determine its political beliefs. If the state can prove this, the state can force the party to redetermine its boundaries and can in effect substitute the state's determination of party boundaries for the party's own determination.

The state's burden of persuasion is a heavy one. ${ }^{60} \mathrm{~A}$ state will have difficulty challenging a political party's designation of who may vote in its primary. A state cannot require an individual to demonstrate subjective adherence to the faith or goals of a political party before participating in the party primary. Courts will regard almost any attempt by the state to

57. A political party seeks to win general elections, and it will not open its primary to voters who will weaken its ability to do so. Such voters include raiders and crossover voters. See infra note 68 . See also Rotunda, Constitutional and Statutory Restrictions on Political Parties in the Wake of Cousins v. Wigoda, 53 TEx. L. REv. 935, 937 (1975) (political parties' desire to win elections is important check on their behavior and permits greater deference to political parties in rulemaking).

58. See supra pp. 124-25. In contrast, deference to the party's determination of who may participate in its primary election increases participation by those with interests at least arguably similar to those of party members. The costs arising from the distorting effects of such participation will be minimal as compared with the costs of state determination of primary participation.

59. For example, a state might successfully challenge the Democratic Party's inclusion of registered Republican Party members in its primary. Such inclusion would render it highly unlikely that primary results would reflect the objectives which the Democratic Party purportedly seeks to promote.

60. This does not mean, however, that a state must tolerate racial discrimination by a political party holding a primary. The state can protect black voters by refusing to give automatic general election ballot access to any political party that excludes blacks from its primary. The state can assert an affirmative mandate in the Fourteenth Amendment not to have its general election used to enhance discrimination against blacks. Racial classifications are invidious; distinctions between party affiliates and non-affiliates are not. See Roberts v. United States Jaycees, 104 S. Ct. 3244, 3253 (1984) (state's compelling interest in eliminating discrimination against women justifies infringement of group members' associational freedoms). 
inquire into an individual's subjective beliefs or motivations as an infringement of the individual's right of privacy or right of association. ${ }^{61}$ In rebutting the inference that a political party has properly confined primary participation to party associates, the state can point only to "objective" external indicators of, or proxies for, that subjective association. ${ }^{62}$ While a state could attempt to prove a logical inconsistency between a political party's statement of its purposes and its demarcation of its boundaries ${ }^{63}$ such an argument is unlikely to succeed when the party stands for very broad, fluid principles. ${ }^{64}$

\section{B. The State's Defense of Its Regulations}

If a political party establishes that a state regulation has expanded or contracted participation in a primary against the party's wishes, the state regulation can stand only if a compelling state interest justifies that infringement. The regulation must also be sufficiently tailored to achieving that compelling state interest. ${ }^{65}$

61. Cf. Shelton v. Tucker, 364 U.S. $479,485-86$ (1960) (requirement that each teacher file affidavit of all organizations to which teacher belonged impaired freedom of association); NAACP v. Alabama ex rel. Patterson, 357 U.S. 449, 460-64 (1958) (right of privacy implicated by membership disclosure requirement).

62. A state may argue that registration as a member of a political party serves as a reasonable proxy for subjective belief. According to this argument, an individual's unwillingness to undertake the minimal step of becoming a political party member indicates a lack of any shared purpose with the party and its members.

A political party, however, can reasonably claim that those who fail to register still possess sufficient shared purpose for an association to exist. The party can argue that unwillingness to register reflects a desire for privacy or a lack of understanding about the implications of registration. Once a political party offers a reasonable alternative explanation for failure to register that preserves the possibility of sufficient shared purpose, the state's inability to examine subjective motivations will make it virtually impossible to overcome the presumption. This inability to overcome the presumption reflects the state's poor choice of proxies for subjective shared purpose. If a state advanced a proxy which the party could not reasonably argue was a poor indicator of shared purpose, the state could overcome the presumption. Registration in a rival political party might be one such proxy. Where there is genuine uncertainty as to whether the state's proxy does indicate shared purpose, however, the presumption protects the right of political association by resolving that uncertainty in favor of the party's definition of its boundaries.

63. Cf. Developments in the Law-Judicial Control of Actions of Private Associations, 76 HARv. L. Rev. 983, 996 (1963) ("Every group has a purpose or function, either express or implied, which might be used as a standard to judge action taken by the organization or its members.") (citation omitted). Even if a state could require a written statement of purpose, however, the state could not require specificity and minute detail in that statement. $C f$. id. at 991 (requirement of strict adherence to purpose will not allow for a group's natural evolution).

64. Given the generality of the principles represented by both the Democratic and Republican Parties, a state will have difficulty arguing that an independent voter shares significantly fewer party beliefs than does a registered party member. This is especially true where there exist only minimal differences between membership and nonmembership, as where a voter may register immediately before participating in a primary.

65. E.g., Kusper v. Pontikes, 414 U.S. 51, 58-59 (1973) (requiring least restrictive means); Dunn v. Blumstein, 405 U.S. 330, 343 (1972) (state's means must be necessary to achieve its goals); NAACP v. Button, 371 U.S. 415, 438 (1963) (state's regulation overly broad and therefore unconstitutional). 


\section{Potential Compelling State Interests}

Courts have labeled "legitimate" many state interests in regulating primaries, ${ }^{66}$ including the preservation of the integrity of the electoral process ${ }^{67}$ and the protection of political parties as viable and identifiable interest groups by protecting parties against raiding and crossover voting. ${ }^{68}$ Because of the peculiar fact patterns in previous challenges, courts have been able to uphold state regulations upon a finding merely of a legitimate state interest. ${ }^{69} \mathrm{~A}$ state defending its regulations against a challenge by a political party, however, must demonstrate that its interests are "compelling." Examination of the various potential state interests reveals that there is no compelling interest for which state regulations requiring or forbidding an open primary constitute a sufficiently tailored means.

\section{a. Preserving the Integrity of the General Election}

While a state has both a constitutional power to preserve the integrity of a general election, ${ }^{70}$ and a compelling interest in doing so, a state regu-

66. Many of these state interests do not affect the open or closed nature of the primary. A state has legitimate interests in decreasing voter confusion and thereby increasing voter rationality, and in ensuring that the winner of an election is the choice of a majority. To promote these interests, the state can limit the number of candidates on the ballot. E.g., American Party v. White, 415 U.S. 767 , 782 n.14 (1974) (ballot access requirement to avoid undue voter confusion); Bullock v. Carter, 405 U.S. 134, 145 (1972) (state interest in limiting number of candidates); Williams v. Rhodes, 393 U.S. 23, 32 (1968) (suggesting this interest in limiting the number of candidates is legitimate but not compelling). A state also has an interest in limiting the ballot to serious candidates in order to promote a vigorous and competitive political system. See Lubin v. Panish, 415 U.S. 709, 715-16 (1974); Bendinger v. Ogilvie, 335 F. Supp. 572, 576 (N.D. Ill. 1971).

67. Rosario v. Rockefeller, 410 U.S. 752, 761 (1973) (state-imposed time deadline on party enrollment for participation in primary); Dunn v. Blumstein, 405 U.S. 330, 345 (1972) (prevention of fraud was compelling interest, but durational residence requirement held unnecessary to achieve that interest); Bullock v. Carter, 405 U.S. 134, 145 (1972) (candidate filing fees unnecessary to achieve state's interest in protecting integrity of political process).

68. Kusper v. Pontikes, 414 U.S. 51, 59-60 (1973) (state regulation insufficiently tailored to serve state interest in preventing raiding); Rosario v. Rockefeller, 410 U.S. at 760 (state regulation legitimately protected against raiding).

"Raiding" occurs when members of one political party vote in the opposing party's primary with the intention of nominating a weak candidate whom the candidate of their "true" party can easily defeat in the general election. See Rosario, 410 U.S. at 760; Note, supra note 2, at 282.

"Crossover voting" includes all voting that cuts across party lines. Unlike raiding, crossover voting does not necessarily involve an intent to distort the primary. See Scott \& Carr, supra note 44, at 280. The evidence concerning the actual effects of these practices on political parties is inconclusive. $C f$. Note, supra note 2, at 282-86 (no avaiiable statistics establish the frequency with which raiding actually occurs); Note, supra note 51, at 307 (same). But see Scott \& Carr, supra note 44, at 280-82 (measuring crossover voting in Washington state primary because of difficulties in measuring raiding).

69. E.g., Rosario v. Rockefeller, 410 U.S. at 758 (plaintiffs had opportunity to enroll in party, hence Court had no need to address First Amendment claims); Yale v. Curvin, 345 F. Supp. 447, 453 (D.R.I. 1972) (not addressing whether prevention of raiding is compelling interest because statute overly broad). Because these past cases did not directly require the courts to find a "compelling" interest, the status of the identified state interests as "legitimate" rather than "compelling" is not conclusive.

70. The constitutional grant of authority to the states to regulate elections authorizes a state to restrict participation in a general election only on a very limited basis. U.S. CoNST. art. I, $\S 2$, cl. 1. 
lation requiring an open or closed primary does not appropriately serve these interests. The state has constitutional power to restrict voting in a general election based on age, ${ }^{71}$ residence, ${ }^{72}$ and citizenship, ${ }^{73}$ and to enforce these restrictions by requiring voters to register. If a state can limit participation in a general election to registered voters, it must also be able to limit participation in a primary election to registered voters in order to ensure that the results of the general election reflect the decision of registered voters only. ${ }^{74}$ Were nonregistered voters to participate in a primary election, they could decisively alter its outcome. Because a state accords the winner of a primary election access to the general election ballot, the results of primaries influence the outcome of a general election by determining the identity of most of the candidates on the general election ballot. ${ }^{76}$ Nonregistered voters who participated in a primary could therefore affect any given candidate's chances of advancing to the general election, and thus affect the chances of that candidate's winning the election. ${ }^{76}$

The state also has a compelling interest in preserving the integrity of

See Lassiter v. Northampton County Bd. of Elections, 360 U.S. 45, 51 (1959) (state can limit registration on the basis of literacy, age, residence, or the existence of previous criminal record). This constitutional grant of authority can also be pre-empted by Congress. Id.

71. Lassiter v. Northampton County Bd. of Elections, 360 U.S. at 51; Gaunt v. Brown, 341 F. Supp. 1187, 1190 (S.D. Ohio), affd, 409 U.S. 809 (1972).

72. Dunn v. Blumstein, 405 U.S. 330, 343-44 (1972); Lassiter v. Northampton County Bd. of Elections, 360 U.S. at 51.

73. Kramer v. Union Free School Dist. No. 15, 395 U.S. 621,625 (1969).

74. A state cannot be certain that the general election reflects the will of qualified voters unless it restricts participation in the primary to such voters. A political party's decision to include nonregistered voters in its primary election would have effects beyond the bounds of the political party which the state legitimately may address. A political party, therefore, cannot extend participation in its primary election to out-of-state voters or to sixteen-year-olds in the face of a state law to the contrary.

Such state regulation is further justified because extending participation in a primary to out-of-state voters would infringe on the notion of representation-by-state implicit in the Constitution. E.g., U.S. CoNST. amend. XIV, § 2 (Representatives to be apportioned among the several states). Thus a state might assert a compelling interest in preserving the idea of representation-by-state contained in the Constitution. $C f$. Dunn v. Blumstein, 405 U.S. at 343-44 (state may preserve the basic conception of a political community). Moreover, as a state provides a primary for the benefit of its own residents, a state might be able to refuse participation to an out-of-state voter. $C f$. $i d$. at 343 (state has compelling interest in preventing participation of out-of-state voters in general election).

These arguments in support of the state's power to restrict primaries to qualified voters apply somewhat less forcefully to a presidential primary, which selects delegates to a national convention, than they do to a primary election for a United States congressional representative or for a state office, in which the state directly incorporates the primary's results into the general election ballot $C f$. Cousins v. Wigoda, 419 U.S. 477, 489-90 (1975) (states have no constitutionally mandated role in selecting presidential candidates; national party convention serves "pervasive national interest in the selection of candidates for national office, and this national interest is greater than any interest of an individual State").

75. As voters must generally choose from among the candidates on the general election ballot, influencing the identity of the candidates on the general election ballot influences the pool of potential winners. A state may provide for write-in candidates, but such candidates are unlikely to win.

76. Such influence can be distinguished from that of a nonregistered voter who donates money to a primary candidate or works on a candidate's campaign. These latter actions are attempts to convince registered voters to support a candidate. The candidate must still be elected by registered voters alone. 


\section{Primary Elections}

the electoral process by allowing each voter to support only one candidate for each office. ${ }^{77}$ The state can therefore prevent a voter from participating in two primary elections for the same general election. ${ }^{78}$ To do otherwise would enable that voter to help place two different candidates for the same office on the general election ballot, thereby giving that voter a greater influence on the general election than other voters have. This disparity would introduce an element of fraud into the general election, just as actually voting for two different candidates for a single office in a general election would constitute fraud. ${ }^{39}$

Neither the state's constitutional power to regulate elections, however, nor its compelling interest in protecting the integrity of the electoral process empowers the state to require an open or closed primary in the face of political party opposition. Voter registration offers a sufficient and far less intrusive means of preventing fraud and of limiting a primary to qualified voters. ${ }^{80}$

\section{b. Protection of Unaffiliated Voters}

Concern for the interests of non-participants affected by a primary does not justify state regulations mandating an open primary. Because of the dominant position enjoyed by the two major political parties in the United States, the outcome of a major party primary will affect unaffiliated individuals by effectively limiting their options in the general election. Political party members' exercise of their constitutional right to advance shared beliefs does not, however, infringe any constitutional right of unaffiliated voters. ${ }^{81}$ Unaffiliated voters have no constitutional right to elect their own preferred candidate; they have only a right to nominate and vote for that candidate. $^{\mathbf{8 2}}$ The party members' constitutional right takes precedence over unaffiliated voters' non-constitutional interests in primary outcomes. A state's attempt to protect unaffiliated voters by enabling them to influ-

77. See American Party v. White, 415 U.S. 767, 785-86 (1974) (state can bar voter from both voting in party primary and signing support petition of independent candidate).

78. Id. at 786 .

79. An individual can offer financial support to two candidates for the same office, however. That money will be used to convince other voters to support that candidate, rather than to enable one voter effectively to cast more than one vote.

80. For example, the state of Wisconsin was able to ensure that the registered voters participating in the open primary system challenged in Denocralic Party cast ballots in only one party's primary. 450 U.S. at 110 n.3, 113.

81. This is true as long as the party's qualifications for affiliation or participation in its primary do not create an invidious classification. See supra note 9.

82. See supra note 10 (independent voters have right to nominate general election candidates, but no right to participate in party primary). Though the monopoly power of the two-party system makes it extremely unlikely that independent candidates and parties can attain political offices through the avenues available to them, no right is infringed. There is no right to elect the candidate of one's choice. 
ence a party's choice of its candidate tampers with the party's associational right to balance the varied interests of its adherents to express an overall shared political ideal..$^{\text {s }}$

Moreover, even if a state could show a compelling interest in enhancing the ability of unaffiliated voters to influence the composition of the general election ballot, a mandatory open-primary requirement would be insufficiently tailored to the achievement of that interest. A state can adequately preserve the rights of unaffiliated voters by according general election ballot access to the representative of any political interest with some degree of public support. ${ }^{84}$

\section{c. Protection of Party Members}

In defending a closed primary against a political party's challenge, a state should not be able to claim a compelling interest in protecting the "best interests" of party members. This alleged state interest reduces itself to an interest in protecting the associational rights of party members by excluding those whom the state considers nonmembers from participating in the party primary. The state's assertion of the "best interests" of party members would be an improper attempt to substitute the state's judgment of the political association's proper boundaries for the party's own determination. The state could attempt to justify this substitution by alleging that the party's judgment relies on erroneous factual assumptions. For example, a state might claim that raiding is more common and more damaging to a party than that party realizes ${ }^{85}$ so that the state must protect the party by closing its primary against the party's will. The state, however, has no claim to special expertise in making this or any similar determination. The political party can judge the likelihood of events such as raiding as well as the state can, and has at least as great an interest in preventing raiding or other participation by those with interests antagonistic to those of party affiliates. In attempting to make such a factual determination without special expertise, the state usurps a right which vests in the political party itself. A state has no right to protect the freedom of association of party members against the party itself.

This does not mean that a state cannot protect the rights of party mem-

83. See supra pp. 125-27.

84. If an independent voter is dissatisfied with this level of influence on the composition of the general election ballot, he or she can always associate with one of the major political parties. Nader, 417 F. Supp. at 843-44, 848-49.

85. The Supreme Court until now has avoided the empirical political science debate over the effects of raiding. See Democratic Party v. Wisconsin, 450 U.S. at 118-19 (deferring to party's study of effects of raiding and crossover voting); cf. Scott \& Carr, supra note 44, at 280 (existence and effects of raiding unclear); Developments, supra note 50, at 1173 (difficult to ascertain whether raiding is serious problem). 
bers against the party leadership's violation of its fiduciary duties. ${ }^{86}$ The state can require, for example, that the party have democratic rulemaking procedures and that the party leadership be accountable to an informed membership. Such state regulation would not infringe on freedom of association because it would not impair the party's determination of the content of its shared ideology.

\section{d. Promotion of the Two-Party System}

States may attempt to defend a closed-primary requirement by asserting an interest in promoting the two-party system in order to "encourage compromise and political stability." party system by encouraging resolution of internal party disputes through primary elections, thus avoiding the splintering of dissident factions from the main party ${ }^{88}$ Even if this interest were compelling, ${ }^{88}$ however, it would not be implicated in a state's decision to hold a closed primary. A party's decision to have an open primary does not harm this state interest. ${ }^{80}$ Indeed, it is the political party's choice of an open primary which would discourage factionalism by forging a broader coalition of interests within a single political party.

The state's interest in a stable two-party system may also refer to the state's interest in preventing election outcomes that will confuse or mislead an electorate which relies on party labels as representative of certain ideologies. ${ }^{91}$ Such an interest amounts to state control over the content and character of political debate: It should not be considered even a legitimate interest, much less a compelling one.

86. Cf. R. Michels, Political Parties 205-25 (E. Paul \& C. Paul trans. 1915) (party leadership tends to seek its own advantage to detriment of rank and file). Leaders may seek to entrench their position and power at the expense of vigorous advancement of the goals of the party membership.

87. Williams v. Rhodes, 393 U.S. 23, 31-32 (1968); see also Republican Party v. Tashjian, Civil No. H 54-548, slip op. at 25-26 (D. Conn. Dec. 5, 1984) (rejecting state's assertion that closed primary necessary to further this interest).

88. A. Bickel, Reform and ContinuITY 22, 87-88 (1971).

89. The Court has yet to determine even the legitimacy of this interest. In Williams $v$. Rhodes the Court distinguished promotion of "the two-party system" from promotion of two particular parties and addressed only the latter when it struck down an Ohio law granting a virtual monopoly to the Democratic and Republican Parties. 393 U.S. at 32.

90. Although outlandish hypotheticals could be imagined in which an open primary would include interests so diverse as to make compromise impossible, a rational political party is extremely unlikely to include such antagonistic interests in its primary. Moreover, in any such hypothetical situation, the lack of any possible shared purpose among the participants would be extreme enough to be objectively evident, thus enabling the state to show that the political party's determination of who participates in its primary election bears no relation to any conception of association. See supra pp. 129-30.

91. See Republican Party v. Tashjian, Civil No. H 54-548, slip op. at 24, 26 (D. Conn. Dec. 5 1984) (rejecting this interest as compelling; nothing legitimate in state's freezing parties in status quo). 


\section{Present Supreme Court Doctrine and the Tailoring of Means and Ends}

State regulations expanding or contracting participation in a primary election in violation of a political party's wishes do not constitute a sufficiently tailored means of serving any permissible goal that has yet been advanced by a state. The requirement that a state's regulation of primary elections be appropriately tailored to achieve the state's goals serves to balance a political party's right of association against a specific public need. The very fact that the doctrine of freedom of association has always permitted some appropriately tailored infringement of political association argues that the right of political association is not-and should not be-absolute. The Supreme Court's present application of the means-ends test, however, vitiates this recognition that public needs must occasionally take precedence over specific rights and transforms the means-ends test into a virtual guarantee of the supremacy of the right of political association.

In the interests of theoretical coherence and analytic clarity, the Court should modify its present approach to the means-ends test. The Court in Democratic Party suggests that even if a court were to consider a state's interest in conducting an open or closed primary compelling, the court should refuse to find a sufficient link between conducting such a primary and imposing the outcome of that primary on a political party's decisionmaking. ${ }^{22}$ This refusal to recognize the connection between the primary election and the party's decisionmaking ignores the basis for the political party's claimed infringement of its right of association, which arises from the state's attempt to influence party decisionmaking. The Court's reasoning also ignores the very reason that a state would want to regulate participation in a primary. ${ }^{93}$ The Court's approach separates the act of voting from the counting of the vote and confers participation in name only.

The Court's approach in Democratic Party completely insulates the right of association from competing compelling state interests and makes the right of association absolute. If an actual compelling state interest exists, freedom of association should give way if the state has chosen the least intrusive means of achieving its interest. Even though no colorably compelling state interest has yet been advanced which could justify a state regulation governing participation in primary elections challenged by a political party, the Supreme Court should modify its present means-ends

92. In Democratic Party, the Court applied this "tailoring" requirement extremely stringently. 450 U.S. at 124-25 (holding that state's interest went to the conduct of primary itself and thus did not justify imposition of primary's results on party decisionmaking).

93. As Justice Powell aptly noted in dissent, the Court's insistence on "tailoring" limited Wisconsin to ineffectual means of preserving its interests. Id. at 134 (Powell, J., dissenting). 


\section{Primary Elections}

test to ensure that, should different fact situations arise, and a compelling state interest come to light, the rights of political party associates will be properly balanced against the needs of society as a whole.

\section{CONCLUSION}

The term "political party" raises two competing images today. One image is that of the Republican or Democratic Party-a broad-based, relatively non-ideological organization. The other image is that of a closelyknit, strongly ideological group. The power to exclude those with an antagonistic political ideology seems most crucial to the freedom of association of this second type of political party. Ironically, however, in practice only the Republican and Democratic Parties will assert this power of exclusion when faced with a state regulation contravening party rules. The ability of more ideological organizations to limit their association to individuals with a similar point of view will be largely self-executing; only those individuals sharing the party's ideology will affiliate with the party.

This tension between ideological and non-ideological political parties' assertion of a freedom of association right to exclude nonmembers need not trouble us, however. Central to our conception of the political party is its ability to determine what its ideological slant and its base of support will be-whether the party will be broad-based and non-ideological or closely-knit and ideological. Thus, deference to the political party's ability to define its own boundaries forms an appropriate cornerstone for the law of state regulation of participation in primary elections, as that ability goes to the very heart of freedom of association.

-Julia E. Guttman 
